\title{
LPP/MLL Fusion Gene
}

National Cancer Institute

\section{Source}

National Cancer Institute. LPP/MLL Fusion Gene. NCI Thesaurus. Code C99432.

A fusion gene that results from a chromosomal translocation $\mathrm{t}(3 ; 11)(\mathrm{q} 28 ; \mathrm{q} 23)$ which fuses exon 8 of the LPP gene to exon 9 of the MLL gene. This rearrangement is associated with treatment-related acute myeloid leukemia. 